\title{
The covenant with Abraham in the context of Africa
}

\author{
J.A.van Rooy \\ Departement Ou \& Nuwe Testament \\ Potchefstroomse Universiteit vir $\mathrm{CHO}$ \\ POTCHEFSTROOM
}

\begin{abstract}
The covenant with Abraham in the context of Africa

The Covenamt of Grace ${ }^{1}$ is God's way of exercising his sovereign rule in personal fellowship with humankind. There are cerlain aspects of Old Testament belief which are mique to it, and which provide the basis for covenant fellowship. These aspects include the personal nature of God, his sovereign rule over history, and the fact that humankind was created in God's image, although it is by nature in flight from God. On this basis it becomes possible for God to seek humankind, to elect a people for Himself, and to conclude a covenant with them which requires faith, love, fellowship and obedience. African religion in its different forms does not provide such a basis, since God is either impersonal, or remote. and not interested in the doings of humankind except in so far as they might threaten the cosmic order. The relationship between God and man is automatic, whether $\mathrm{He}$ is conceived of as Creator, or as the first ancestor, or indiscriminately, as the source of energy.
\end{abstract}

\section{Introduction}

The Bantu proverb says, "A person is a person through another person" (Sotho: Motho ke motho ka e mong). The Old Testament parallel would have been, "Man is man through God" (cf. De Groot \& Hulst, 1952:261). The world view of Bantu Africa is thoroughly anthropocentic (Tempels, 1946:34); that of the Old Testament thoroughly theocentric (De Groot \& Hulst, 1952:35). According to the Old Testament perspective, one really becomes a person only in relationship to God. That relationship is moulded in the form of a covenant(s), which in its turn is based upon a number of prerequisites specific to Biblical religion. These are discussed in the following paragraphs which specifically highlight the biblical background of the covenant with Abraham.

1 Professor Lion-Cachet in his studics showed particular interest in the nature of the covenant of grace in the Old Testament. His doctoral thesis was written on the topic of the relationship between the Abrahamic and the Sinaitic covenants (Lion-Cachet, 1976). It secms therefore fitting to offer this contribution on the same topic by way of expressing my appreciation for him as thcologian. 


\section{God is a Person}

\subsection{The gods of the Semites and of Africa}

The gods of Canaan and the Semitic world are in essence nothing more than personified forces of nature (Von Rad, 1962, Vol. 1:218), and their myths have the purpose of explaining natural phenomena such as the seasons, life and death, storms, rain, drought, and fertility. Their rites, intended to reactify the myths, were supposed to be a way of manipulating the forces of nature. For this reason, there can be no question of an intimate relationship of love between god and man in those religions (Eichrodt, 1961:45). The gods were much too impersonal for that. They were, to be sure, presented in personal tenms; they did not have, however, any genuine personality, but were merely mythological personifications. They could just as easily have been conceptualized in animal form, and indeed this often happened (Eichrodt, 1961:46). The connection between the god and the worshipper among Israel's neighbours was in essence the mere communication of divine vitality (Eichrodt, 1961:45).

There are more than one concept of God in Africa, the most representative being those of an impersonal force (Van Rooy, 1995:14-17), a remote God (Van Rooy, 1995:18-21), and that of the first ancestor (Van Rooy, 1995:22-24).

\subsection{Yahweh is a Person, who desires fellowship with man}

Yahweh never reveals himself otherwise than as a Person with a sovereign moral will, addressing man as person to person and calling him to fellowship with the living God. He plans, wills, speaks, acts and feels like a human being. His personhood is part of his essential being. "A divine will which so expressly makes a human community its goal cannot be conceived as a dark, impersonal power or as an unconscious life-force" (Eichrodt, 1961:209).

The fellowship which the sovereign, personal God brings about with humankind, his image and likeness, is the most basic element of the whole revelation of the Old Testament, its meaning and purpose, or rather, of the whole of Scripture, since this statement is just as valid for the New Testament (Vriezen, 1974:193, 171). The fact that God is a Person, and desires fellowship with mankind, provides the basis for the establishment of the covenant of grace.

\section{Yahweh is the sovereign Lord of history}

In ancient Semitic mythology there was no room for a real historic approach to religion and the gods. Man was caught in a cyclical view of time, which corresponded to the mythological explanation of seasons and other phenomena of nature. The gods were not above this cycle or in control of it, but were irrevocably bound to it. Baal was subjected to the fate of having to die every 
year (as was Tammuz of the Babylonians or Sandon of the Hittites), and it was the function of Anath to conquer the god Moth every year again, in order to be able to revive Baal, be united to him and thus to inaugurate the rainy season every autumn (Jacob, 1962:47-52).

As for African concepts of (jod: if God is the Force Virale in the cosmos (Van Rooy, 1995:14-17), "it" might be regarded as the driving force of history. But since in that case God is not personal, He can in no way be regarded as being in sovereign control of history, guiding it by his decisions according to his plan and pleasure, overruling the "natural course of events", just as little as an electric current can guide the way it is used.

Among the Bantu peoples, there are very few traces of God's influence in history. Thixo/INkosi yeZulu is so remote that he is not relevant to history. He might at most be perceived to stand at the beginning of history, involved in some way or other with the creation of man, but otherwise he is too far removed from humankind on the hierarchical ladder to be approachable. His presence is actually so dangerous that it has to be avoided at all costs.

In the Old Testament, the mythological, cyclical view of the gods and nature was totally displaced by a historical one. God is the sovereign Creator, who remains in total control of history. If the account of creation itself stands in time, myth has once and for all lost its ratio (Von Rad, 1962, Vol. 1:136,139; cf. Miskotte, 1939:65, 66). This implies that (iod can choose a people and guide its fortunes in such a way as to execute his design in history.

\section{Man as God's image (םלs)}

Notwithstanding man's creatureliness, he is given the honour of having been created "in the image and likeness of God". Whatever the exact ineaning of the tenns is God's image, man can both rule and have fellowship with God as one person with another, however great the differences between God as Creator and man as creature may otherwise be. See also Jacob, 1958:152. As God's image, Inan is "a YOU addressed by God and accountable to God" (Westermann, 1968:208 my own translation - see also $209,217,218$ ).

Man has "a share in the personhood of God" (Eichrodt, 1967:126); and as a being capable of self-awareness and self-determination he is open to being addressed by God and capable of responsible conduct.

Man can never be conceived to have been created in the image of Modimo of the Sotho peoples - not as long as man is a person and Modimo is an impersonal force. Therefore the whole idea of fellowship with Modimo is preposterous 
If, on the other hand, God is the first ancestor (Mwari of the Shona and Venda), then man is genealogically related to him and God has to be conceived as the image of man. But this has nothing to do with the righteousness, holiness and knowledge about which the Bible teaches us. In this case, God, being the highest in the hierarchy of forces, is the ruler, but this attribute is not carried over to all his descendants in the sense that all men are rulers over creation.

\section{Man in flight from God and God seeking humankind}

Man is by nature a person in flight from God, avoiding the encounter with God, hiding from God (Gen. 3:8). Even from these first chapters of Genesis it is clear that it is not man that seeks God, as is so frequently implied in African myths. Man is the rebel, the fugitive. God is the one who looks for man after man has rejected God; God restores the broken fellowship, even in his judgement (McVeigh, 1974:56, 57, 59). The consequences for the covenant are that, if ever there should be a covenant bond between God and humankind, God would have to take the initiative

\section{- God seeking humankind}

As Helberg (1976 Vol. 1:41, 42) points out, it happens time and again that, when man by his apostasy ends in a state of spiritual death, God intervenes and restores man to life by restoring the fellowship. After the fall, God seeks his children in the garden and speaks to them calling them back from hiding. When apostasy on a large scale brings the divine punishment of the Flood over the earth, God intervenes and saves the believing Noah and his family (Genesis 7). When humanity again rebels against God at Babel, God calls one man from among them in order to make hiin a great nation and concludes a covenant with him (Genesis 12 ; 15; 17). This man is Abraham.

\section{God's election}

Among the religions of ancient peoples this concept of election is totally unique. Neither in Semitic religion, nor in Egyptian or Persian religions, is there any analogy to it. Neither can therc be any analogy, since Yahweh is the only God who has revealed himself as a God of love, and election is a manifestation of electing love. The gods of the Ancient Near East were related to their "respective peoples" by virtue of their existence as local or national deities. Every people and country simply had its own gods, who were never supposed to have been elected to be the gods of those particular peoples. Neither is there any record of a people who had answered the call of a god to become its people, as Abraham answered God's call to become the father of his people. Every member of a people automatically, by virtue of his birth into that people, became a worshipper of the national god(s). 
It must immediately be clear to anyone that to speak of love and election presupposes a personal will, even emotion, in Yahweh. Mbiti (1970:53-55) lists quite a number of instances of Bantu-speaking peoples who believe in predestination in the sense that everything is planned by God and stands under his control. The Tswana consider Modimo to be responsible for moulding the destiny of each individual. That, however, is self-evident if Modimo is the allpervading divine power which pulses through everything. This is no predestination of a personal will, but the control of an irresistable force, which is itself "mechanically" predetermined as a matter of course. "IT" works according to set rules, and the same rules automatically include everything and everyone. There is, however, no personal will, and therefore also no personal love or election. "IT" has no feelings, whether positive or negative. It neither loves nor hates.

Or if, on the other hand, one refers to another model of the deity, that of the first chief and ancestor, there may well be interest in the offspring of the god, but it is difficult to imagine any love, and one never hears mention of it. Man is not Mwari's next of kin, he is separated from Mwari by countless generations - so many steps on the hierarchical ladder. If there is any relationship at all, that is not the result of election, but of genealogy. The relationship is not metaphorical, it is realistic, physical

If we look at the third model, that of INkosi yeZulu, the far-away, uninvolved Creator-God - how can there be love or election if the deity is not in the least interested in the weal and woe of these puny human beings on earth? If there is interest at all, it is the universal interest of a Creator, without preference for any of the creatures.

\section{God's covenant of grace itself}

God's kingdom means that he rules in intimate covenant fellowship with man. The way his electing love is manifested, is called the covenant of grace. In the Preface to the English edition of his Theology of the Old Testament, Walter Eichrodt (1961:17) expresses the opinion that "The concept of the covenant enshrines Israel's most fundamental conviction, namely its sense of a unique relationship with God", and he then proceeds to take the covenant concept as the unifying theme for his whole theology of the Old Testament. Vriezen (1974:167) makes an observation that is of extreme importance for the comparison between the Old Testament and any pagan concept of God in his relationship with man, including that of Africa: "When the Old Testament regards the relationship between God and the people as a covenant-relationship, this means that the relationship is not looked upon as natural but as placed in history by Yahweh." The importance of this doctrine becomes evident only when we see it against the background of the other ancient oriental religions. Often the latter represent the 
relation between the chief deity and his people as a natural unity: deity, country and people bear the same name (Asshur). The gods are frequently actually looked upon as the physical parents of the nations (Vriezen, 1974:167). One is reminded of the Mwari concept of the Shona/Venda. This fact highlights the unique character of the covenant concept, which is just as unique as that of election, of which it is the outcome and application. Yahwist faith was not a national religion, neither was it the result of the reflection of natural man, it was the result and creation of God's gracious election of and self-revelation to Israel, and it could be terminated (Nicholson, 1986:210).

\subsection{The nature of the covenant of grace}

The covenant establishes a personal bond between God and his people. Thus the covenant is the way in which God exercises his personal rule.

The second important statement about the covenant with Abraham is that it is a covenant of grace, God's sovereign grace which creates a relationship between him and man where humanly speaking, no relationship could have been possible.

Personal communion is what distinguishes covenant religion from that of all Israel's neighbours, and also from African religion. It is the essence of true religion, in which only the regenerated child of the covenant can feel at home. and which is his only possible home.

Theologians from Africa who try to tell the world that there is no essential difference between African traditional religion and biblical religion should consider this point first. In the African concept of God, instances of this constant, loving, joyous communion with God are totally lacking, and the examples of sporadic communication (not communion!) with him are so few and far between that they always strike scholars as noteworthy because of their very scarcity!

\subsection{Unilateral in its origin}

(In Reformed dogmatic terminology, the term "monopleuric" is usually employed to express the idea of "unilateral".) As many scholars point out (inter alia Von Rad, 1962, Vol. 1:132; Craigie, 1976:22-24; Thompson, 1974:18-20), "comparison of Ancient Near Eastern treaties, especially those made by the Hittites in the fourteenth and thirteenth centuries B.C., with passages in the Old Testament has revealed so many things in common between the two, particularly in the matter of form, that there must be some connection between these suzerainity treaties and the exposition of the details of Jahweh's covenant with Abraham ..." (Von Rad, 1962, Vol. 1:132). Although scholars such as Nicholson (1986:81) have come to the conclusion that the analogies between the suzerainity treaties 
and the covenant concept of the Old Testament are not sufficient to warrant the supposition that the Old Testament drew on those treaties for the form of the covenants, there seems to be so many similarities that it is worth while to note them. It would also seem that persons who downplay those analogies have the motivation of disproving the ancient origin of the covenant idea, and of returning to the outdated evolutionary theories of Julius Wellhausen (Nicholson, 1986:82). All having been said, those analogies still shed light upon the structure of the covenant. At least one can assume that the covenant as concluded with Abraham was no totally strange phenomenon, but had analogies in contemporary political treaties (Lion-Cachet, 1976:147).

The unilateral nature of the covenant is graphically illustrated in the actions of God and Abraham in the establishing of the covenant according to the record of Genesis 15. Abraham is not consulted beforeland; he is simply instructed to prepare the animals for the concluding of the covenant. Then Yahwel establishes the covenant according to his own decision. Abraham is Yahweh's vassal.

However, Yalıweh deviates from the accepted pattern of the suzerainity treaties: He alone treads the path formed by the slaughtered beasts, thereby indicating that He limself - and He alone - takes the responsibility for the keeping of the covenant.

\subsection{The indicative: the promises of the covenant}

One of the most cardinal cliaracteristics of the covenant with Abraham is that the indicative is of primary importance in it. The apostle Paul, schooled in rabbinic theology and steeped in the covenant tradition, usually calls the covenant "the promise" (as in Gal. 3:16,21,22). For understanding the covenant and living according to it, it is essential to understand and practise the right relationship between its two major elements, the indicative and the imperative, and to maintain the balance between them in a biblical way. Both are essential, and under- or over-estimating either of these elements has always been detrimental to the health of the community of the people of God (Van Rooy, 1987:22-25). Neglecting the indicative element leads to legalism without the basis of God's electing love and covenant grace. Neglecting the imperative leads to antinomianism and a life which is not to God's honour.

In the relationship between the indicative and the imperative, it is essential to keep in mind that the indicative is the constitutive factor of the covenant: it is God's creative act, and without it there would be no basis for the imperative.

African customary law is by nature legalistic. The reason for customs is given simply as: "It is not done!" or: "That is the way our people do it!" This legalistic idea of life is carried over into the Christian church, and the new way of 
life is presented as a new set of rules in the same mould: "It is not done!" This, however, is not acceptable to the younger people of Africa, who are in rebellion against all authority, especially when they see no positive function for that authority, but a mere limiting of their personal freedom. A legalistic religion has no long-tern future in Africa. People should be shown the indicative of God's love, salvation and promises as the basis of his law.

The primary indicative of the covenant is framed as a promise "to be your God and the God of your descendants after you" (Gen. 17:7).

This unilateral origin of the covenant brings with it several very important consequences.

- In the first place, it gives direction and significance to history (Dymess, 1979:125). God has a purpose with his people, and in their history he fulfils this purpose. It is their obligation to know this purpose and to live in accordance with it.

- Secondly, it brings assurance (if not security!) to life. The covenant is a stable element in the life of God's people. It provides a firm foundation for trust in God.

- Thirdly, it also provides the foundation for a life in God's service. But most important of all, the basic demand is to know Yahweh, "that is, to enjoy a personal and living relationship with this God" (Dyrness, 1979:125).

Summarizing the character of the life of God's people under the covenant of grace, it can be described as a life under grace, a life in freedom, a life in hope, a life in love (Gerber, 1989:39).

\subsection{God's covenant love}

It is of great importance to note that in the suzerainity treatises no mention was made of love of the suzerain towards his vassals, but only of the vassals towards the suzerain (McCarthy, 1973:15). This "love" was of course no more than the expression of mere formal loyalty to the suzerain. Very often it was imposed upon an unwilling vassal, and just as often vassals took the first opportunity to rebel against the suzerain whenever they thought they had a good chance to get away with it (Bright, 1960:267).

All the promises of the covenant can be summarized in the one word which is so often used of the relations within the covenant, to wit 7 , "loyal, constant, faithful love". This term gives expression to the enduring nature of God's covenant love, which is not nullified even by the disloyalty or shortcomings of his human partner. When Abraham's faith turned out to be less than total reliance 
upon God in his dealings with the pharao, Yalıweh nevertheless protected him against harn (Gen. 12:10-19).

This tenn - חס - is of special importance in the context of this attitude, because it serves to highlight one of the distinctive features of biblical, covenant religion when compared to ancient Semitic religion and especially to the religion of the Sotho/Tswana people and other African peoples. We refer to the feature that "the covenant community [communion?] between Yalıweh and Israel found its aptest expression not so much in the attribute of power, which can be paralleled in all religions, as in a whole series of quite different propositions. Preeminent among these is that of Yahwelı's loving kindness (hesed)" (Eichrodt, $1961: 232)$. We do not propose to argue for this meaning of come to be generally accepted by Old Testament scholars (Jacob, 1958:104).

This concept was entirely absent in all other national religions of Israel's neighbours, in particular Baalistic religion. The whole set-up and purpose of Baalism was of a naturalistic nature. The gods were the personifications of natural phenomena (Albright, 1968:101-131), and the beliefs about them reflected all the unpredictabilities and fickleness of the precarious weather conditions of Palestine and vicinity. Power is an attribute inherent in nature, but loyal love presupposes a personal, loving God.

There is no need to elaborate on the comparison between biblical covenant religion and the image of God anong the Sotho/Tswana. If Modimo is an impersonal selo se se boitshegang (fearful, numinous thing), $I T$ will manifest its reaction to the disregarding of taboos as a matter of course, and its dangerous, numinous spirit power will attomatically be released against the culprit. There might be magical means of circunnenting or escaping this reaction, but there can be no question of forgiveness which rests on loyal, forbearing love, just as there can be no covenant.

If God is Mwari of the Shona and Venda peoples, then forbearance is not the result of loyal covenant love, not of forgiveness, but of the indulgence of a cosmic grandparent. If he is Thixo'INkosi yeZulu, he is power pure and simple, but the personal communion and love which might enable him to forgive is not a factor that can be reckoned with. Retribution is swift and automatic, like what happens when a force of nature is disregarded.

African religion, including the syncretistic religion of many of the African independent churches, focuses first and foremost not on forgiveness or fellowship with God, but on power and the manipulation of forces (Van Rooy, 1964:17). Syncretistic African movements share one characteristic: obsession with power. 
In his wide-ranging researches, Mbiti (1970:31) could come across only three examples of people who speak of the mercy of God, and those are all from the more northern peoples, who call God leza or Mulungu.

\subsection{The imperative: the demands of the covenant}

\subsubsection{Faith as man's covenant obligation}

It was just as true for the old as for the new covenant that "without faith it is impossible to please God" (Heb. 11:6). When Yalıweh came to Abraham with the promise of a natural heir and a numerous offspring, as an introduction to and part of the covenant he was about to conclude with him, Abraham answered by faith: "Abraham believed the LORD, and he credited it to him as righteousness" (Gen. 15:6). The first imperative of the covenant is faith. The faith-relationship is in itself the righteous fulfilment of the covenant fellowship on man's part (Eichrodt, 1967:279). By faith man indicates his willingness to be included in God's covenant: he trusts God, takes him at his word and puts himself in his hands (De Groot \& Hulst, 1952:275-276; also Preusz, 1992:171).

Fellowship with God is an essential concomitant of faith in God. Therefore, fellowship with God is the deepest longing of the Old Testament believers. God Himself expresses the desire for fellowship and intimacy in the words, "Shall I hide from Abraham what I am about to do?" (Gen. 18:17), a statement which earned for Abraham the title "the friend of God" among later authors (Jes. 2:23).

Among Israel's neighbours, as among the people of Africa, there was very little scope, if any at all, for personal decision in the field of religion. Religion was by definition "people's religion", the religion of the people as a whole, or, in the case of less sedentary societies, of the extended family. Everything was regulated according to set patterns. Individual decision in the relationship with the deity, or individual faith in and fellowship with the deity, was non-existent. If there was any communication with the deity at all, it was about matters of national concern and not of individuals.

Moreover, faith and fellowship have their roots in a personal self-revelation of the living God, in his redemptive deeds and in the fellowship which he himself initiated. Faith must rest on something secure, something real. There is, however, no reality in pagan religion. Baal was a fiction, a projection of man's need for security in agriculture and the fertility of man and beast. What trust man had, he put in his own rites which had the purpose of reviving and assisting Baal against Moth; but there could be no security, because there was no real and secure ground for man's faith in the gods. There could be no real faith, because there was no real knowledge (in the biblical sense of ירע - a personal knowledge which involved care and fellowship - Preusz, 1992:171) of the gods. Therefore, 
there could be no fellowship, since fellowship presupposes this personal acquaintance with a faithful God.

By the same token, if one can speak of "faith" in Modimo or Mwari, it is the same kind of faith as one has in one's ancestor spirits. It is not a faith with substance in reality, resting on a personal knowledge of the living God. There is no existential knowledge (דעת) of the living God, and therefore there can be no fellowship of faith.

If God is INkosi yeZulu or Thixo of the Nguni, no representative of these peoples would admit to personally knowing him. At most, people know about him. The knowledge is not existential. The less one has to do with him, the better for one's own well-being and safety. If, as the Zulu people say, he has amawala, then there cannot even be any hope of security with him, since he is fickle and unpredictable.

\subsubsection{Obedience, the concomitant of faith}

In the Near Eastern treaties the vassal was expected to be absolutely subjected and obedient to the suzerain. He was not permitted to conclude a treaty with any other king, and he had to render service and provide troops in the battles of the great king.

Likewise, believing Abraham was obliged to be totally subject and obedient to Yahweh when he was called upon to leave his country and his family (Gen. 12:1). The God whom he came to know, demanded total commitment, every day and in all circumstances (De Groot \& Hulst, 1952:78). That was what was implied by the 7 חֶ of the covenant that was required of him. As Yahweh keeps his the covenant relationship, so man has to keep his $7 \underset{7}{\text {. }}$. By chesed man best attains to the imitation of God and the chesed he shows to his neighbour is always chesed Elohim" (2 Sam. 9:3; 1 Sam. 20:14; Jacob, 1958: 174). At the institution of the rite of circumcision, God addresses Abraham with the words, "Live in my presence and be blameless" (Gen. 17:1). God Himself refers to this again when revealing to Abraham how He is about to execute his judgement over Sodom and Gomorral: "For I have chosen him, so that he will direct his children and his household to keep the way of the LORD ..." Gen. 18:19). Finally Abraham's obedience is put to the most severe test possible, when he is instructed to go and sacrifice his only son (Genesis 22).

This injunction to love God reminds one of what one Zulu informant told AxelIvar Berglund (1976:42) about INkosi yeZulu: "We do not love him as we love the shades. He is too far away to love. One can only love the one that is near." And Mbiti (1970:219) writes on the same topic: "This search after God's attention is utilitarian and not purely spiritual; it is practical and not mystical. As 
far as our sources are concerned, African peoples do not 'thirst after God' for his own sake alone. They seek to obtain what he gives, be that material or even spiritual; they do not seem to search for him as the final reward or satisfaction of the human soul and spirit" - and that is actually what love for God is!

Just as the imperative of obedience can never be divorced from the indicative of salvation, so the imperative of love and obedience can never be divorced from the indicative of God's covenant love. In both cases it would lead to dead, legalistic religion. This is a serious problem in churches world-wide, but especially in African churches. The injunctions and instruction of young Christians very often tend to follow the pattern of traditional African culture, which consists of a series of "don'ts". In traditional culture, in which the individual is integrated in a very rigid system of authority with strong and effective sanctions, this kind of instruction might be effective to a degree, but in modem, open society, especially since the structures of parental and communal authority have collapsed, this kind of instruction is totally ineffective, quite apart from the fact that it is theologically unacceptable in Christian churches.

\subsubsection{The fear of the Lord}

While Israel's neighbours sought to escape their fear of the gods either by means of ritualistic magic or by turning to other gods for protection against the less sympathetic ones, the fear of the believing Israelite was modified by quite another factor. Their fear of God was not one of abject terror, because he revealed himself to them as the God of the covenant (Dyrness, 1979:161, 162). This selfrevelation of Yahweh as the God of $7 \not ु$, loving loyalty to the covenant partner, transformed their fear from "a sense of numinous terror to a reverential awe in which trust already predominates ... unshakeable confidence and willing obedience, humble renunciation of one's own way and unconditional adherence to the goal of God's leading" (Eichrodt, 1967:271, 272). The term is even often used synonymously with trust (Vriezen, 1974:175).

This confident trust has no parallel in the religions of the Ancient Near East or of Africa. The will of those nature gods "is too little reliable and too ambiguous for men to be able to credit them with a coherent total purpose ... Anxiety remains one of the basic elements of Babylonian piety" (Eichrodt, 1967:272).

In Africa, anxiety over the anger or jealousy of the spirits is often the driving force of what religious ritual there is. "Look here," the spirits are addressed during the libation offerings, "we are giving you your due; now go away and leave us in peace. Do not cause disasters any longer; do not let our children fall ill or our crops fail." 
There is one instance of the idea of the fear of God in Africa which resembles the Old Testament concept in meaning, and that is the concept of mampuba among the Ila people, significantly a people who have a strongly theistic concept of God, Leza (McVeigh, 1974:19). McVeigh (1974:19) calls this "a complex emotion, made up of fear, reverence and affection: the specific religious emotion".

Because in the covenant relationship the will of God was revealed to Israel in his law, the irrational element in their fear was repressed in favour of an attitude of reverence and obedience for a divine will which can be known (Eichrodt, 1967:273). The fear of God thus attains a strong ethical element. It is no longer predominantly avoidance, as the Zulu and Xhosa peoples avoid INkosi yeZulu, but it becomes humble obedience in fellowship with a loving God (see also De Groot \& Hulst, 1952:267)

\subsubsection{The cult and prayer}

The cult is not an expendable aspect of religious life, it is a genuine expression of a living faith. Man needs forms in which to give expression to his gratitude to and reverence and love for God (De Groot \& Hulst, 1952:285). Actually, the absence of a cult often indicates a concept of God in which he is not very real or relevant. People from Africa often say, "Why should we bring offerings to God? He does not need our food; we do not need his fellowship" (McVeigh, 1974:110, 111).

Then it is also important to remember that, in contrast to the religion of the gentiles, for Abraham the cult was by no means the only way of communication between God and man. Personal prayer was widely practised quite apart from the cult among Abraham's descendents (Neh. 1:4-11; 9:2; Job 7:20; 40:3f.; Jer. 14:7-9; Dan. 9:4f.), a tradition which carried on Abraham's own informal, though reverent dialogue with God (Gen. 18:22-33).

The virtual absence of any cult, as in the cases of Modimo and INkosi yeZulu, reflects the beliefs about lack of personal involvement of God in the everyday life of man on earth. In the view of almost all Bantu peoples, the idea is that God does not need food. He also has no fellowship with human beings; therefore there is no need for offerings to him (McVeigh, 1974:110,111). The Mwari cult at Matonjeni, which consists of chiefs sending deputations there for consultations accompanied by gifts, reflects the belief that Mwari is a national god who might be interested in the weal and woe of the tribe as a whole, but never in that of individuals.

As for the individual offerings: By way of contrast we may mention the offerings of Bantu Africa first. Prayer and offering are both essential parts of communication with the spirits. Usually the offering is poured out over the head 
of an animal, or over certain cult objects, and then the requests are made for help or for the spirits to cease their interference in the life of the living. Requests cannot be made to the spirits without offerings to them. The spirits need the offerings, although in the case of highly exceptional prayers which are sometimes made to the High God in the time of crisis, requests can sometimes be made without offerings, as in the case of prayer to Modimo of the Tswana/Sotho (Setiloane, 1976:75f.).

Gift offerings of this nature are the only type recorded ainong Bantu people, and the spirits are dependent on those for their existence. In the Old Testament it is abundantly clear that God does not need the sacrifices. That is the main message of Psalm 50: "Will I eat the flesh of bulls, or drink the blood of goats? Offer unto God the sacrifice of thanksgiving ..."

Most cases of prayers to the supreme Deity which Mbiti (1975) and Shorter (1975) mention are from peoples living in northern Africa, such as the Boran of Kenya, who pray to God every morning and evening, expressing their trust in him and asking for his protection and blessing (Shorter, 1975:124, 125). The Dinka of the Sudan seem to have an especially close relationship to God, judging by the examples of trustful prayers given by Mbiti $(1975: 137,142)$. On the other hand, the majority of the prayers to ancestor spirits recorded by Mbiti (1975:101-108) are from southem Africa.

In the Old Testament - and the idea of the covenant will not be understood if this is not clear to the reader - this fellowship is what religion is all about. Offerings and prayers are in the first place expressions of this fellowship. God rules in personal covenant fellowship with redeemed man, and this is what his kingdom, his rule, means. Apart from this, there is no true religion, no true knowledge of God, no way of pleasing God.

I do not argue that this is the only aspect of true religion. Of course religion has its ethical dimensions, both in relation to God and to one's fellow man, but these ethical dimensions are squarely based on the vertical relationship with God.

\section{Bibliography}

ALBRIGHT, W.F. 1968. Yahweh and the gods of Canaan. London : Athlone Press.

BERGLUND, Axel-Ivar. 1976. Zulu thought-patterns and symbolism. London: Hurst.

BRIGHT, J. 1960. A history of Israel. London : SCM Press

CRAIGIE, P.C. 1976. The Book of Deuteronomy. Grand Rapids : Eerdmans.

DE GROOT, J. \& HULST, A.R. 1952. Macht en wil. De verkondiging van het Oude Testament aangaande God. Nijkerk : Callenbach.

DYRNESS, W. 1979. Themes in Old Testament theology. Exeter : Paternoster Press 
EICHRODT, W. 1961. Theology of the Old Testament, Vol 1 London : SCM Press.

EICHRODT, W. 1967. Theology of the Old Testament, Vol II. London : SCM. Press.

GERBER, J M. 1989 Verbondsperspektief op menswees Acta Theologica, 9(2):27-41, Desember

HELBERG, J.L 1976. Openbaringsgeskiedenis van die Ou Testament. Twee dele Potchefstroom : Pro Rege

JACOB, E. 1958. Theology of the Old Testament. London : Hodder \& Stoughton

JACOB, E. 1962 Ras Sjamra-Ugarit en het Oude Testament. Nijkerk : Callenbach.

LION-CACHET, F.N 1976. Die kontinuiteit van die Abrahamitiese verbond in die opset van die Sinaitiese verbond. Potchefstroom : PU vir CHO. (Proefskrif - Th.D.)

MBITI, J.S 1970. Concepts of God in Africa. London: SPCK

MBITI, J.S.J. 1971. New Testament eschatology in an African background Oxford : Oxford University Press.

MBITI, J.S. 1975. The prayers of African religion. London : SPCK

McCARTHY, D J 1973. Old Testament covenant. A survey of current opinions Oxford Blackwell

McVEIGH, M.J. 1974. God in Africa. Conceptions of God in African traditional religion and Christianity Cape Cod : Claude Stark.

MISKOTTE, K.H. 1939. Edda en Thora Een vergelijking van Germaansche en Israelitische religie. Nijkerk: Callenbach.

NICHOLSON, E.W. 1986. God and his people Covenant and theology in the Old Testament. Oxford : Clarendon Press

PREUSZ, H.D. 1992. Theologie des Alten Testaments, Band II. Israels Weg mit JiWH. Stuttgart : Kohlhammer.

SETILOANE, G.M. 1976. The image of God among the Sotho-Tswana. Rotterdam : Balkema

SHORTER, A. 1975. Prayer in the religious traditions of Africa Nairobi : Oxford University Press.

TEMPELS, P. 1946. Bantoe-filosofie Antwerpen : De Sikkel.

THOMPSON, J.A. 1974. Deuteronomy An introduction and commentary. London : IVP.

VAN ROOY, J.A. 1964. Sinkretisme in Vendaland. Potchefstroom : PU vir CHO. (Skripsie - Th.M.)

VAN ROOY, J.A. 1987. Kwa Sizabantu. Dieptestudie van 'n herlewing. Vereeniging Reformatoriese Uitgewers.

VAN ROOY, J.A. 1995. Yahweh and Modimo. The relationship between God and man in the Old Testament seen in the context of African concepts of God. Potchefstroom PUCHE. (Dissertation - Th D)

VON RAD, G. 1962. Old Testament theology, 2 vols. New York: Harper \& Row.

VRIEZEN, Th. C. 1974 Hoofdlijnen der theologie van het Oude Testament Wageningen Veenman en Zonen. 
WESTERMANN, C. 1968. Genesis 1-11. (In Biblischer Kommentar Altes Testament. Neukirchen : Neukirchener Verlag.) 